\title{
Chalcogenylation of Naphthalene Derivatives Catalyzed by Iron(III) Chloride and Potassium lodide
}

\author{
Diego Seckler ${ }^{\mathrm{a}}$ \\ Eduardo Q. da Luz \\ Gabriel L. Silvério ${ }^{a}$ \\ Gul Badshaha \\ David B. Lima \\ Emerson A. Abreu ${ }^{a}$ \\ Breidi Albach ${ }^{b}$ \\ Ronny R. Ribeiroc \\ Daniel S. Rampon*a \\ a Laboratory of Polymers and Catalysis (LaPoCa), Department \\ of Chemistry, Federal University of Paraná-UFPR, P. O. Box \\ 19061, Curitiba, PR, 81531-990, Brazil \\ danielrampon@quimica.ufpr.br \\ b Health Department, Unicesumar-The University Center of \\ Maringá, Curitiba, PR, 81070-190, Brazil \\ breidi.albach@gmail.com \\ c Department of Chemistry, Federal University of Paraná-UFPR, \\ P. O. Box 19061, Curitiba, PR, 81531-990, Brazil \\ ronny.ribeiro@ufpr.br
}

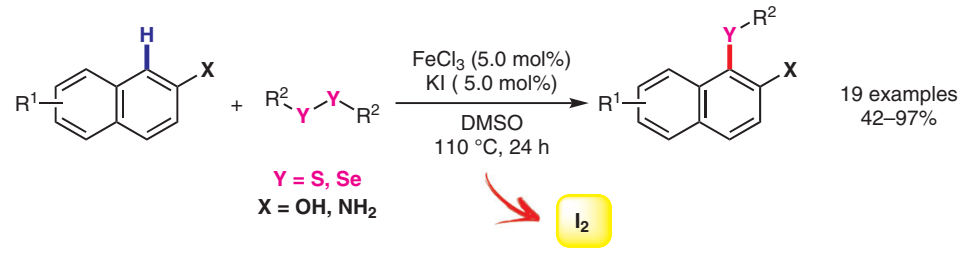

Received: 21.12 .2020

Accepted after revision: 05.03.202

Published online: 01.04.2021

DOI: 10.1055/s-0040-1706748; Art ID: st-2020-v0639-I

Abstract We have developed an efficient chalcogenylation of electron-rich naphthalene derivatives catalyzed by $\mathrm{FeCl}_{3}$ and $\mathrm{KI}$. The methodology provides access to several nonsymmetrical diorganoyl chalcogenides (S, Se) by selective $\mathrm{C} 1$ chalcogenylation of 2-naphthols or 2naphthylamines using simple and cheap catalysts. Several control experiments supported the hypothesis that a redox reaction between $\mathrm{Fe}(\mathrm{III})$ and $\mathrm{KI}$ produces $\mathrm{I}_{2}$, which catalyzed the chalcogenylation.

Key words iron catalysis, potassium iodide catalysis, sulfanylation, selenylation, naphthylamines, naphthols

Substituted naphthalene derivatives are a recognized class of compounds that form the main structural scaffolds of several relevant natural products. ${ }^{1}$ These derivatives also have found outstanding applications in materials science, ${ }^{2}$ and numerous commercially available drugs have such moieties in their core structures. ${ }^{3}$ As a result, many efforts have been directed toward the development of new methods for the regioselective synthesis of substituted naphthalene compounds. ${ }^{4}$ In particular, the efficient and selective conversion of a $\mathrm{C}\left(\mathrm{sp}^{2}\right)-\mathrm{H}$ bond into a C-chalcogen (S, Se, Te) bond in naphthalene derivatives has received considerable attention ${ }^{5,6}$ because of the potential therapeutic applications of the organochalcogen compounds, ${ }^{7}$ as well their exceptional properties as organic optoelectronic materials. ${ }^{8}$ As examples of the importance of organochalcogenides, the nonsymmetrical organosulfide vortioxetine is an antidepressant used to treat adults with major depressive disor- der, ${ }^{7 i, j}$ and quetiapine is an atypical antipsychotic that is indicated for the treatment of schizophrenia and bipolar disorders, including bipolar depression (Figure 1). ${ }^{7 k, 1}$ Moreover, a number of selenium-containing bicyclic arenes have been also reported to have a range of attractive biological properties, including 5-lipoxygenase inhibition, ${ }^{7 \mathrm{~m}}$ anticancer, ${ }^{7 \mathrm{n}}$ anti-inflammatory, ${ }^{70}$ and anti-Alzheimer activities, ${ }^{9 \mathrm{q}}$ among others. ${ }^{7 \mathrm{p}-\mathrm{r}}$
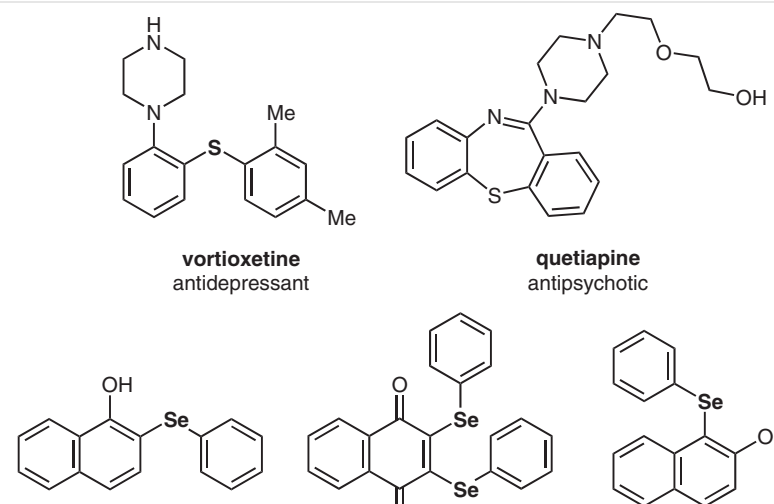<smiles>O=C1C([Se]c2ccccc2)=C([Se]c2ccccc2)C(=O)c2ccccc21</smiles><smiles>Oc1ccc2ccccc2c1Oc1ccccc1</smiles>

5-lipoxygenase inhibitor
Figure 1 Biologically relevant sulfur- or selenium-containing bicyclic arenes

Given the prominent status of the naphthalenes functionalized with organochalcogen groups, the development of cheap and efficient methods for preparing these compounds is highly desirable. Generally, the chalcogenylation 
of bicyclic arenes and hetarenes is performed by using various electrophilic organochalcogen reagents, which are often formed in situ, in combination with electron-rich aromatic compounds. ${ }^{5 \mathrm{a}-\mathrm{j}, 51, \mathrm{~m}, 6 \mathrm{a}-\mathrm{c}, 9 \mathrm{a}-\mathrm{o}}$ Among electron-rich naphthalenes, the regioselective chalcogenylation of naphthols remains challenging, and only recently have some feasible methods been described. In this respect, the transitionmetal-free sulfanylation of naphthols has received attention. However, many of the existing methods require handling of difficult reagents that require multistep preparation. ${ }^{5 a-i}$ Additionally, the base-promoted chalcogenylation of naphthols seems to be an efficient and cheap method, although the presence of a hydroxy group is a prerequi- site. $^{\text {5i,6c-e }}$ Moreover, an electrochemical selenylation of several activated arenes at Pt electrodes in an undivided electrochemical cell has also been described. ${ }^{\text {aa }}$

Transition-metal-catalyzed direct chalcogenylations of 1- or 2-naphthols have also been developed but, until now, were limited to sulfanylations exclusively and required the use of $\mathrm{Pd},{ }^{5 \mathrm{j}} \mathrm{Cu},{ }^{5 \mathrm{k}} \mathrm{Ag},{ }^{51}$ or $\mathrm{V}^{5 \mathrm{~m}}$ catalysts. Cobalt catalysis permits a chelation-assisted direct sulfanylation of naphthols and phenols, ${ }^{5 \mathrm{n}}$ a difficult task under metal-free conditions. Driven by the increasing interest in chemical utilization of abundant and nontoxic transition metals, iron catalysis has attracted considerable attention in the field of organic synthesis because of the high natural abundance, environmentally benign character, low cost, and low toxicity of this

Table 1 Optimization of the Reaction Conditions ${ }^{\mathrm{a}}$

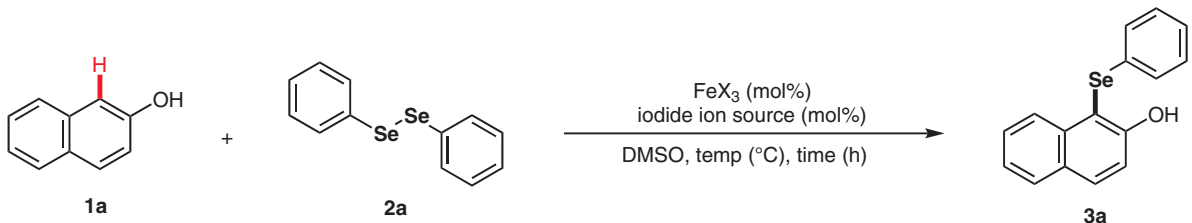

1a

$2 a$

$3 a$

\begin{tabular}{|c|c|c|c|c|c|}
\hline Entry $^{\mathrm{a}}$ & Catalyst (mol\%) & Additive (mol\%) & Time $(\mathrm{h})$ & $\operatorname{Temp}\left({ }^{\circ} \mathrm{C}\right)$ & Yield ${ }^{\mathrm{b}}(\%)$ \\
\hline 1 & $\mathrm{FeCl}_{3}(2.5)$ & $\mathrm{KI}(2.5)$ & 24 & 110 & 87 \\
\hline 2 & $\mathrm{FeCl}_{3}(5.0)$ & $\mathrm{KI}(5.0)$ & 24 & 110 & $>99(97)^{c}$ \\
\hline 3 & $\mathrm{FeCl}_{3}(10)$ & KI (10) & 24 & 110 & 69 \\
\hline 4 & $\mathrm{FeCl}_{3}(15)$ & KI (15) & 24 & 110 & 35 \\
\hline 5 & $\mathrm{FeCl}_{3}(20)$ & KI (20) & 24 & 110 & 9 \\
\hline 6 & $\mathrm{FeCl}_{3}(30)$ & $\mathrm{KI}(30)$ & 24 & 110 & 6 \\
\hline 7 & $\mathrm{FeCl}_{3}(5.0)$ & - & 24 & 110 & 38 \\
\hline 8 & - & $\mathrm{KI}(5.0)$ & 24 & 110 & - \\
\hline 9 & $\mathrm{FeCl}_{3}(5.0)$ & $\mathrm{KI}(5.0)$ & 24 & 90 & 53 \\
\hline 10 & $\mathrm{FeCl}_{3}(5.0)$ & $\mathrm{KI}(5.0)$ & 24 & 70 & 17 \\
\hline 11 & $\mathrm{FeCl}_{3}(5.0)$ & $\mathrm{KI}(5.0)$ & 24 & 120 & - \\
\hline 12 & $\mathrm{FeCl}_{3}(5.0)$ & $\mathrm{KI}(5.0)$ & 12 & 110 & 38 \\
\hline 13 & $\mathrm{FeCl}_{3}(5.0)$ & $\mathrm{KI}(5.0)$ & 18 & 110 & 48 \\
\hline 14 & $\mathrm{FeCl}_{3}(5.0)$ & KF (5.0) & 24 & 110 & 11 \\
\hline 15 & $\mathrm{FeCl}_{3}(5.0)$ & $\mathrm{KCl}(5.0)$ & 24 & 110 & 6 \\
\hline 16 & $\mathrm{FeCl}_{3}(5.0)$ & $\mathrm{KBr}(5.0)$ & 24 & 110 & 12 \\
\hline 17 & $\mathrm{FeBr}_{3}(5.0)$ & $\mathrm{KI}(5.0)$ & 24 & 110 & 20 \\
\hline 18 & $\mathrm{FeCl}_{3} \cdot 6 \mathrm{H}_{2} \mathrm{O}(5.0)$ & KI (5.0) & 24 & 110 & 3 \\
\hline 19 & $\mathrm{Fe}\left(\mathrm{NO}_{3}\right)_{3} \cdot 9 \mathrm{H}_{2} \mathrm{O}(5.0)$ & $\mathrm{KI}(5.0)$ & 24 & 110 & 16 \\
\hline 20 & $\mathrm{Fe}_{2} \mathrm{O}_{3}(5.0)$ & $\mathrm{KI}(5.0)$ & 24 & 110 & 2 \\
\hline 21 & $\mathrm{Fe}_{2}\left(\mathrm{CO}_{3}\right)_{3}(5.0)$ & $\mathrm{KI}(5.0)$ & 24 & 110 & 8 \\
\hline 22 & $\mathrm{PhFeO}_{7}$ & $\mathrm{KI}(5.0)$ & 24 & 110 & 18 \\
\hline 23 & $\mathrm{Cu}_{2} \mathrm{O}(5.0)$ & $\mathrm{KI}(5.0)$ & 24 & 110 & 9 \\
\hline
\end{tabular}

a Reaction conditions: 1a $(0.50 \mathrm{mmol}), 2 a(0.25 \mathrm{mmol}), \mathrm{FeX}_{3}$ (mol\%), additive (mol\%), anhyd DMSO (2.0 mL), air atmosphere.

b Determined by GC/MS with anthracene as a standard.

c Isolated yield. 
metal. ${ }^{10,11}$ Despite the several advantages of iron, its use in direct chalcogenylations remains underdeveloped. Fe(III)catalyzed C3 sulfanylations of indoles by diorganoyl disulfides $^{11 a}$ or thiols ${ }^{11 b}$ have been reported. More recently, our group reported a mild and efficient $\mathrm{Fe}(\mathrm{III})$-catalyzed direct C3 chalcogenylation of indoles, and we assessed the mechanistic effects of iodide ions in the system. ${ }^{11 \mathrm{c}}$ As part of our continuing interest in organochalcogen chemistry $6 \mathrm{~d}, 11 \mathrm{c}, 12,13$ and in the design of environmentally friendly chalcogenylation reactions, we report a regioselective $\mathrm{C} 1$ chalcogenylation of electron-rich naphthalene derivatives by using a cheap system involving $\mathrm{FeCl}_{3}$ and iodide ions under air atmosphere.

Our study began by evaluating the reaction of 2-naphthol (1a) with diphenyl diselenide (2a) as model substrates. From our seminal mechanistic studies, ${ }^{11 c}$ we chose a combination of iron (III) chloride $\left(\mathrm{FeCl}_{3}\right)$ and potassium iodide (KI) in dimethyl sulfoxide (DMSO), known to give molecular iodine $\left(\mathrm{I}_{2}\right)$, which we hoped would catalyze the chalcogenylation. Therefore, in our first experiment we employed $2.5 \mathrm{~mol} \%$ of $\mathrm{FeCl}_{3}$ and $2.5 \mathrm{~mol} \%$ of $\mathrm{KI}$ as an additive in DMSO, which gave an $87 \%$ yield of 1-(phenylselanyl)-2-naphthol (3a) after 24 hours at $110{ }^{\circ} \mathrm{C}$ under an air atmosphere (Table 1 , entry 1 ). This success prompted us to improve the yield and to evaluate the role of each reagent in the transformation. Fortunately, the yield was improved to $99 \%$ on running the reaction with $5.0 \mathrm{~mol} \%$ of $\mathrm{FeCl}_{3}$ and $5.0 \mathrm{~mol} \%$ of $\mathrm{KI}$ (entry 2), whereas further increases in the catalyst and additive loadings to $10,15,20$, or $30 \mathrm{~mol} \%$ did not improve the yield of 3a (entries 3-6). Carrying out the reaction with Fe$\mathrm{Cl}_{3}$ (5.0 mol\%) and without $\mathrm{KI}$ provided compound $\mathbf{3 a}$ in $38 \%$ yield (entry 7 ), demonstrating the important role of iodide ions in this system. Furthermore, the desired product was not detected in the absence of $\mathrm{FeCl}_{3}$ (entry 8). In the next step, we screened the effects of temperature and time on the reaction system (entries 9-13). Decreasing the temperature from $110{ }^{\circ} \mathrm{C}$ to $90{ }^{\circ} \mathrm{C}$ or $70{ }^{\circ} \mathrm{C}$ furnished lower yields of 3a (entries 9 and 10), and no product was detected when the reaction was performed at $120{ }^{\circ} \mathrm{C}$ (entry 11 ). Shorter reaction times considerably reduced the yield of the expected product (entries 12 and 13). Because the oxidation of iodine ion by $\mathrm{Fe}(\mathrm{III})$ rapidly produces $\mathrm{I}_{2},{ }^{14}$ the involvement of this redox reaction in our system was evaluated by using alternative additives. We obtained a lower yield of 3a when $\mathrm{KF}, \mathrm{KCl}$, or $\mathrm{KBr}$ was used (entries 14-16), suggesting a particular role for the combination of $\mathrm{Fe}(\mathrm{III})$ and iodide ions in this reaction. In the next step, several other $\mathrm{Fe}(\mathrm{III})$ sources were evaluated (entries 17-22); however, 3a was obtained in low yields in these cases. We have to point out a detrimental effect of water on the yield, as observed with $\mathrm{FeCl}_{3} \cdot 6 \mathrm{H}_{2} \mathrm{O}$ (entry 18 ).

Considering the hygroscopic nature of $\mathrm{FeCl}_{3}$, one would expect a reduction of the yield as a result of contamination of the catalyst with water, but the high yield of 3a under the optimized conditions ruled out any related issue. Finally, to verify that the reaction was not catalyzed by trace amounts of copper impurities, ${ }^{15}$ an experiment was carried out with $\mathrm{Cu}_{2} \mathrm{O}$ (Table 1, entry 23 ), and only a $9 \%$ yield of the expected product was obtained. This result confirmed the key role of $\mathrm{Fe}(\mathrm{III})$ in this method.

A variety of solvents were also evaluated under the reaction conditions. On running the reaction in DMF, NMP, THF, or xylene, a low yield was observed $(9,13,8$ and $3 \%$, respectively), and only trace amounts of 3a were detected in $\mathrm{MeCN}$ or $\mathrm{CH}_{2} \mathrm{Cl}_{2}$. An exceptional reaction yield was observed only in DMSO, (Table 1 , entry 2 ), which suggests a specific solvent effect on this reaction. This is probably related to regeneration of the $\mathrm{I}_{2}$ generated in situ. ${ }^{6 \mathrm{~b}, 9 \mathrm{~m}-\mathrm{o}, 11 \mathrm{c}, 16-18}$

Having optimized the reaction conditions (Table 1, entry 2), we evaluated the scope of this method with regard to the electron-rich naphthalene derivative and the diorganoyl dichalcogenide partner (Schemes 1 and 2). In general, moderate to good yields were observed with diaryl diselenides bearing electron-donating or electron-withdrawing groups (3b-e). However, bulky diaryl diselenides gave products $\mathbf{3 f}$ and $\mathbf{3 g}$ in moderate yields, suggesting that steric effects on the diselenides influenced the yield of this reaction. We observed that a longer reaction time of 32 hours improved the yield of $\mathbf{3 g}$ to 75\%. Further, 6-bromo-2-naphthol gave a good yield of $\mathbf{3 h}$ (75\%), and the reaction was also effective for dialkyl diselenides (3i). The amounts of $\mathrm{FeCl}_{3}$ and $\mathrm{KI}$ required to give good selenylation yields from 2 naphthylamine and 6-hydroxyquinoline were evaluated. The best results were obtained by using $30 \mathrm{~mol} \%$ of $\mathrm{FeCl}_{3}$ and $30 \mathrm{~mol} \%$ of $\mathrm{KI}$, which provided a $99 \%$ yield of $\mathbf{3 j}$ and an $80 \%$ yield of 3k. Because the well-known acid-base reaction of $\mathrm{Fe}$ (III) and $n$ electrons in the nitrogen atoms of anilines or pyridines can deactivate the catalyst and the electron-rich naphthalene derivative, the use of higher catalyst amounts is plausible. Additionally, no selenylation of 2-methoxynaphthalene was observed and only the starting materials were detected on a detailed inspection of the GC/MS trace.

The method was successfully extended to diorganoyl disulfides 4 (Scheme 2), which reacted with electron-rich naphthalenes to give products $\mathbf{5 a} \mathbf{a}-\mathbf{h}$ in moderate to excellent yields. Again, moderate to good yields were obtained with diaryl disulfides bearing electron-donating or electron-withdrawing groups (5b-e) and with a functionalized 2-naphthol (5f). The sulfanylation of 2-naphthylamine and 6-hydroxyquinoline required higher catalyst and additive loadings to obtain good to excellent yields ( $\mathbf{5 g}$ and $\mathbf{5 h}$ ). The product $5 \mathbf{i}$ was not obtained from the reaction of 2-methoxynaphthalene with diphenyl disulfide.

To gain some insight into the mechanism of this reaction, we conducted a series of control experiments (Scheme 3 ). Under the optimized reaction conditions, the addition of 2.0 equivalents of the radical scavenger TEMPO or hydroquinone (HQ) (Scheme 3a) decreased the yield of product 


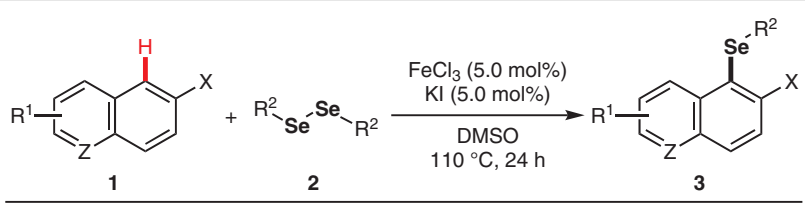<smiles>Oc1ccc2ccccc2c1[Se]c1ccccc1</smiles><smiles></smiles><smiles>COc1ccc([Se]c2c(O)ccc3ccccc23)cc1</smiles>
$3 a$
$97 \%$<smiles>Oc1ccc2ccccc2c1[Se]c1ccc(Cl)cc1</smiles><smiles>Oc1ccc2ccccc2c1[Hg]c1cccc(C(F)(F)F)c1</smiles>

$\mathbf{3 e}$
$73 \%$

$75 \%$<smiles>Oc1ccc2ccccc2c1Oc1cccc2ccccc12</smiles>

$3 \mathrm{~g}$ $45 \%, 75 \%$ a<smiles>Nc1ccc2ccccc2c1[Se]c1ccccc1</smiles>

3j $42 \%, 58 \%$, $70 \%,{ }^{\mathrm{c}} 99 \%{ }^{\mathrm{d}}$<smiles>Oc1ccc2cc(Br)ccc2c1[Se]c1ccccc1</smiles>
$3 \mathbf{h}$
$75 \%$<smiles>Oc1ccc2ncccc2c1[Se]c1ccccc1</smiles>
$3 \mathbf{k}$
$80 \% f$<smiles>Oc1ccc2ccccc2c1[Se][Ba]Br</smiles>

$3 i$<smiles>COc1ccc2ccccc2c1[Se]c1ccccc1</smiles>

31
$0 \%$

Scheme 1 Selanylations of naphthalene derivatives catalyzed by $\mathrm{FeCl}_{3}$ and KI. Reagents and conditions: 1 (0.5 mmol), 4 (0.25 mmol), $\mathrm{FeCl}_{3}(5.0$ $\mathrm{mol} \%), \mathrm{KI}(5.0 \mathrm{~mol} \%)$, anhyd DMSO $(2.0 \mathrm{~mL})$, air atmosphere, $110^{\circ} \mathrm{C}, 24$ h. Isolated yields are reported. a $32 \mathrm{~h} .{ }^{\mathrm{b}} \mathrm{FeCl}_{3}(10 \mathrm{~mol} \%), \mathrm{KI}(10 \mathrm{~mol} \%),{ }^{\mathrm{c}}$ $\mathrm{FeCl}_{3}$ (20 mol\%), KI (20 mol\%). ${ }^{\mathrm{d}} \mathrm{FeCl}_{3}$ (30 mol\%), $\mathrm{KI}$ (30 mol\%).

3a, which at first glance might suggest a radical pathway. However, when the reaction was developed with $2.5 \mathrm{~mol} \%$ of $\mathrm{I}_{2}$, the theoretically maximum amount produced from $\mathrm{FeCl}_{3}(5.0 \mathrm{~mol} \%$ ) and $\mathrm{KI}$ (5.0 mol\%) under the standard conditions, product 3a was obtained in 79\% yield (Scheme $3 b$ ), which would suggest an ionic pathway. Our previous electron paramagnetic resonance experiments on the chalcogenylation of indoles catalyzed by $\mathrm{FeCl}_{3}$ and $\mathrm{KI}$ ruled out a radical mechanism. ${ }^{11 \mathrm{c}}$ The harsher conditions $\left(110^{\circ} \mathrm{C}\right) \mathrm{em}-$ ployed in the chalcogenylation of the naphthalene deriva-

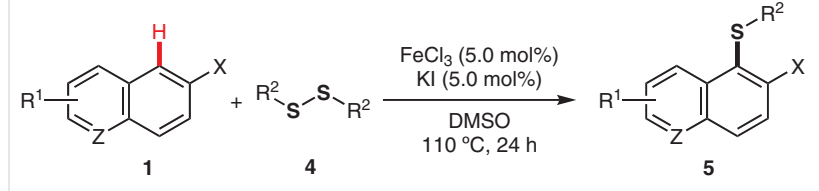<smiles>COc1ccc(Sc2c(O)ccc3ccccc23)cc1</smiles><smiles>Nc1ccc2ncccc2c1Sc1ccccc1</smiles><smiles>COc1ccc2ccccc2c1Sc1ccccc1</smiles>

$5 \%$

Scheme 2 Sulfanylations of naphthalene derivatives catalyzed by $\mathrm{FeCl}_{3}$ and KI. Reagents and conditions: $\mathbf{1}(0.5 \mathrm{mmol}) . \mathbf{4}(0.25 \mathrm{mmol}), \mathrm{FeCl}_{3}(5.0$ $\mathrm{mol} \%), \mathrm{KI}(5.0 \mathrm{~mol} \%)$, anhyd DMSO $(2.0 \mathrm{~mL})$, air atmosphere, $110^{\circ} \mathrm{C}$, for $24 \mathrm{~h}$. Isolated yields are reported. ${ }^{\mathrm{a}} \mathrm{FeCl}_{3}$ (30 mol\%), $\mathrm{KI}$ (30 mol\%).

tives probably permit the recognized side reactions between $\mathrm{Fe}(\mathrm{III})$ and $\mathrm{TEMPO}^{19 \mathrm{a}-\mathrm{d}}$ or $\mathrm{HQ}^{20}$ poisoning the $\mathrm{Fe}(\mathrm{III})$ that is required for the oxidation of iodide ions.

This was supported by performing the reactions in the presence of TEMPO or HQ at $60{ }^{\circ} \mathrm{C}$ for longer reaction times (Scheme 3c), whereupon the yield of 3a increased to $47 \%$ and $41 \%$, respectively. Importantly, the essential contribution of iodide ions to the high reaction yield is also compelling evidence that corroborates an ionic mechanism involving the formation of $I_{2}$ in situ (Table 1, entries 2 and 14-16). The crucial effect of solvent on this system was also assessed (Scheme 3d). An experiment performed under an inert atmosphere (argon) and in strictly anhydrous conditions using a polar aprotic solvent (DMF) and ten equivalents of DMSO gave a $70 \%$ yield of $\mathbf{3 a}$, indicating that this solvent plays a role in the regeneration of the $\mathrm{I}_{2}$ formed in situ from HI. ${ }^{6 b, 9 m-0,11 c, 16,17}$ Also, when the reaction was performed in DMF under an $\mathrm{O}_{2}$ atmosphere the yield was $23 \%$, which further supports the role of DMSO in the oxidation of HI (Scheme 3e). Finally, when the standard reaction was performed in darkness, the yield was 95\% (Scheme 3f), which ruled out any photochemical pathway. 


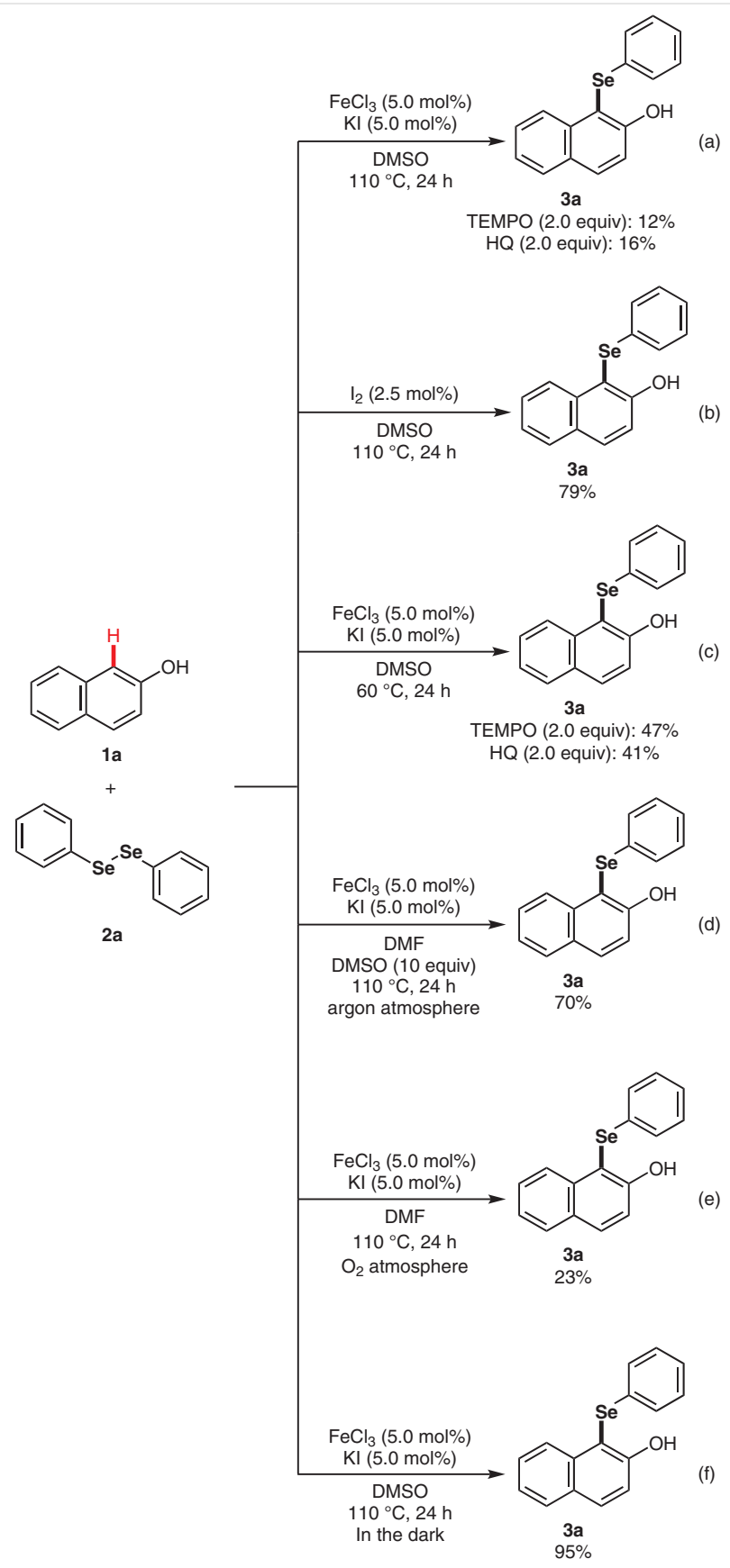

Scheme 3 Control experiments. Isolated yields are reported.

On the basis of these results and previous reports, ${ }^{6 \mathrm{~b} 9 \mathrm{~m}-}$ o,11c,16,17 a plausible catalytic cycle was proposed (Scheme 4 ). Initially, a rapid redox reaction between $\mathrm{Fe}(\mathrm{III})$ and KI produces $I_{2}$ in the reaction medium, ${ }^{14}$ in accordance with previous studies. ${ }^{11 \mathrm{c}}$ Subsequently, the oxidation of the diorganoyl dichalcogenide ( 2 or 4 ) by $\mathrm{I}_{2}$ produces an electrophilic chalcogen species (RY-I) that undergoes an electrophilic aromatic substitution at the $\mathrm{C} 1$ position of the electron-rich bicyclic arene catalyzed by $\mathrm{Fe}(\mathrm{III})$, which is still in the system, affording the corresponding product ( $\mathbf{3}$ or $\mathbf{5}$ ) and HI. The molecular iodine catalyst is restored by the reaction of HI with DMSO, completing the catalytic cycle. ${ }^{6 b, 9 m-0,11 c, 16,17}$

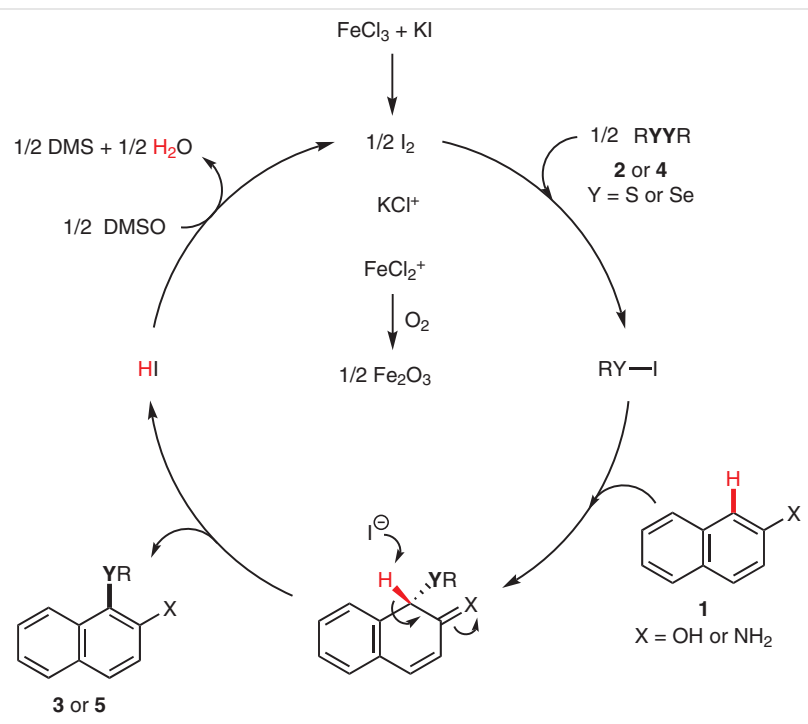

Scheme 4 Proposed catalytic cycle

In summary, a chalcogenylation of electron-rich naphthalene derivatives catalyzed by $\mathrm{FeCl}_{3}$ and $\mathrm{KI}$ has been developed. ${ }^{21}$ The method features simple and cheap catalysts and gives nonsymmetrical diorganoyl chalcogenides (S, Se) by selective $\mathrm{C} 1$ chalcogenylation of 2-naphthols or 2-naphthylamines. Control experiments supported the hypothesis that iodide ions are oxidized by Fe(III) to produce molecular iodine, which is the actual catalyst for the reaction in this system.

\section{Conflict of Interest}

The authors declare no conflict of interest.

\section{Funding Information}

This study was financed in part by the Coordenação de Aperfeiçoamento de Pessoal de Nível Superior - Brasil (CAPES) - Finance Code 001, CNPq Process: 400400/2016-2, Fundação Araucária and UFPR.

\section{Supporting Information}

Supporting information for this article is available online at https://doi.org/10.1055/s-0040-1706748. 


\section{References and Notes}

(1) (a) Huang, J.-Q.; Fang, X.; Tian, X.; Chen, P.; Lin, J.-L.; Guo, X.-X.; Li, J.-X.; Fan, Z.; Song, W.-M.; Song, M.; Chen, F.-Y.; Ahati, R.; Wang, L.-W.; Zhao, Q.; Martin, C.; Chen, X.-Y. Nat. Chem. Biol. 2020, 16, 250. (b) Atkinson, D. J.; Brimble, M. A. Nat. Prod. Rep. 2015, 32, 811. (c) McCulloch, M. W. B.; Barrow, R. A. Molecules 2005, 10, 1272. (d) Bräse, S.; Encinas, A.; Keck, J.; Nising, C. F. Chem. Rev. 2009, 109, 3903. (e) Bringmann, G.; Günther, C.; Ochse, M.; Schupp, O.; Tasler, S. Fortschr. Chem. Org. Naturst. 2001, 82, 249. (f) Widhalm, J.; Rhodes, D. B. Hortic. Res. 2016, 3 , 16046.

(2) (a) Teng, D.-G.; Wei, X.-Y.; Yang, Z.; Zhu, Q.-J.; Gao, H.-S.; Li, J.H.; Zong, Z.-M. Macromol. Chem. Phys. 2020, 221, 1900302 DOI: 10.1002/macp.201900302. (b) Kalla, R. M. N.; Reddy, S. S.; Kim, I. Catal. Lett. 2019, 149, 2696. (c) Xu, N.; Li, Y.; Wu, R.; Zhu, R.; Zhang, J.; Zakeeruddin, S. M.; Li, H.; Li, Z.-S.; Grätzel, M.; Wang, P. Chem. Eur. J. 2019, 25, 945. (d) Watson, M. D.; Fechtenkötter, A.; Müllen, K. Chem. Rev. 2001, 101, 1267. (e) Guo, X.; Kim, F. S.; Seger, M. J.; Jenekhe, S. A.; Watson, M. D. Chem. Mater. 2012, 24, 1434. (f) Yan, L.; Popescu, F.; Rao, M. R.; Meng, H.; Perepichka, D. F. Adv. Electron. Mater. 2017, 3, 1600556. (g) Al Kobaisi, M.; Bhosale, S. V.; Latham, K.; Raynor, A. M.; Bhosale, S. V. Chem. Rev. 2016, 116, 11685. (h) Shimizu, T.; Ding, W.; Kameta, N. Chem. Rev. 2020, 120, 2347. (i) Cao, D.; Liu, Z.; Verwilst, P.; Koo, S.; Jangili, P.; Kim, J. S.; Lin, W. Chem. Rev. 2019, 119, 10403. (j) Pron, A.; Gawrys, P.; Zagorska, M.; Djurado, D.; Demadrille, R. Chem. Soc. Rev. 2010, 39, 2577. (k) Bhosale, S. V.; Jani, C. H.; Langford, S. J. Chem. Soc. Rev. 2008, 37, 331. (l) Wu, W.; Liu, Y.; Zhu, D. Chem. Soc. Rev. 2010, 39, 1489. (m) Hamilton, G. R.; Sahoo, S. K.; Kamila, S.; Singh, N.; Kaur, N.; Hyland, B. W.; Callan, J. F. Chem. Soc. Rev. 2015, 44, 4415. (n) Bisoyi, H. K.; Kumar, S. Chem. Soc. Rev. 2010, 39, 264. (o) Polycyclic Arenes and Heteroarenes: Synthesis Properties, and Applications; Miao, Q., Ed.; Wiley-VCH: Weinheim, 2016, 307.

(3) (a) Sharma, M.; Prasher, P. RSC Med. Chem. 2020, 11, 184. (b) Cui, H.; Kamal, Z.; Ai, T.; Xu, Y.; More, S. S.; Wilson, D. J.; Chen, L. J. Med. Chem. 2014, 57, 8340. (c) Naumiec, G. R.; Jenko, K. J.; Zoghbi, S. S.; Innis, R. B.; Cai, L.; Pike, V. W. J. Med. Chem. 2015, 58, 9722. (d) Stockdale, T. P.; Williams, C. M. Chem. Soc. Rev. 2015, 44, 7737. (e) Makar, S.; Saha, T.; Singh, S. K. Eur. J. Med. Chem. 2019, 161, 252. (f) Staker, B. L.; Hjerrild, K.; Feese, M. D.; Behnke, C. A.; Burgin, A. B. Jr.; Stewart, L. Proc. Natl. Acad. Sci. U.S.A. 2002, 99, 15387. (g) Pommier, Y. Nat. Rev. Cancer 2006, 6, 789. (h) Taylor, R. D.; MacCoss, M.; Lawson, A. D. J. Med. Chem. 2014, 57, 5845. (i) Taylor, R. D.; MacCoss, M.; Lawson, A. D. J. Med. Chem. 2017, 60, 1638.

(4) (a) Matsuda, T.; Izutsu, T.; Hashimoto, M. Eur.J. Org. Chem. 2020, 2020, 306. (b) Zhou, S.; Wang, J.; Wang, L.; Song, C.; Chen, K.; Zhu, J. Angew. Chem. 2016, 128, 9530. (c) Zhang, X.; Sarkar, S.; Larock, R. C. J. Org. Chem. 2006, 71, 236. (d) Kang, D.; Kim, J.; Oh, S.; Lee, P. H. Org. Lett. 2012, 14, 5636. (e) Duan, S.; Herndon, J. W. Org. Lett. 2008, 10, 1541. (f) Ma, H.; Hu, X.-Q.; Luo, Y.-C.; Xu, P.-F. Org. Lett. 2017, 19, 6666. (g) Wang, Q.; Zheng, N. ACS Catal. 2017, 7, 4197. (h) Chan, C.-K.; Wang, H.-S.; Tsai, Y.-L.; Chang, M.-Y. RSC Adv. 2017, 7, 29321. (i) Cao, X.; Cai, B.-G.; Xu, G.-Y.; Xuan, J. Chem. Asian J. 2018, 13, 3855. (j) Shu, W.-M.; Liu, S.; He, J.-X.; Wang, S.; Wu, A.-X. J. Org. Chem. 2018, 83, 9156. (k) Sbi, S.; Mkpenie, V.; Tanemura, K.; Rohand, T. Synlett 2020, 31, 903. (1) Peng, S.; Sun, Z.; Zhu, H.; Chen, N.; Sun, X.; Gong, X.; Wang, L. Org. Lett. 2020, 22, 3200. (m) Prévost, S. ChemPlusChem 2020 , 85,476 .
(5) (a) Parumala, S. K. R.; Peddinti, R. K. Green Chem. 2015, 17, 4068. (b) Wang, D.; Zhang, R.; Lin, S.; Yan, Z.; Guo, S. RSC Adv. 2015, 5, 108030. (c) Xiao, F.; Chen, S.; Tian, J.; Huang, H.; Liu, Y.; Deng, G.-J. Green Chem. 2016, 18, 1538. (d) Lin, Y.-m.; Lu, G.-p.; Wang, G.-X.; Yi, W.-b. Adv. Synth. Catal. 2016, 358, 4100. (e) Xu, Z.-b.; Lu, G.-p.; Cai, C. Org. Biomol. Chem. 2017, 15, 2804. (f) Raghuvanshi, D. S.; Verma, N. RSC Adv. 2017, 7, 22860. (g) Wang, D.; Guo, S.; Zhang, R.; Lin, S.; Yan, Z. RSC Adv. 2016, 6, 54377. (h) Hostier, T.; Ferey, V.; Ricci, G.; Gomez Pardo, D.; Cossy, J. Org. Lett. 2015, 17, 3898. (i) Xiao, F.; Tian, J.; Xing, Q.; Huang, H.; Deng, G.-J.; Liu, Y. ChemistrySelect 2017, 2, 428. (j) Saravanan, P.; Anbarasan, P. Org. Lett. 2014, 16, 848. (k) Xiao, F.; Chen, S.; Li, C.; Huang, H.; Deng, G.-J. Adv. Synth. Catal. 2016, 358, 3881. (1) Gogoi, P.; Gogoi, S. R.; Kalita, M.; Barman, P. Synlett 2013, 24, 873. (m) Maeda, Y.; Koyabu, M.; Nishimura, T.; Uemura, S. J. Org. Chem. 2004, 69, 7688. (n) Rostami, A.; Khakyzadeh, V.; Zolfigol, M. A.; Rostami, A. Mol. Catal. 2018, $452,260$.

(6) (a) Meirinho, A. G.; Pereira, V. F.; Martins, G. M.; Saba, S.; Rafique, J.; Braga, A. L.; Mendes, S. R. Eur. J. Org. Chem. 2019, 2019, 6465. (b) Silva, L. T.; Azeredo, J. B.; Saba, S.; Rafique, J.; Bortoluzzi, A. J.; Braga, A. L. Eur. J. Org. Chem. 2017, 4740. (c) Xiong, X.; Yeung, Y.-Y. ACS Catal. 2018, 8, 4033. (d) Lima, D. B.; Santos, P. H. V.; Fiori, P.; Badshah, G.; Luz, E. Q.; Seckler, D.; Rampon, D. S. ChemistrySelect 2019, 4, 13558. (e) Ghosh, T.; Mukherjee, N.; Ranu, B. C. ACS Omega 2018, 3, 17540. (f) Saba, S.; Rafique, J.; Franco, M. S.; Schneider, A. R.; Espíndola, L.; Silva, D. O.; Braga, A. L. Org. Biomol. Chem. 2018, 16, 880.

(7) (a) Nogueira, C. W.; Zeni, G.; Rocha, J. B. T. Chem. Rev. 2004, 104, 6255. (b) Reich, H. J.; Hondal, R. J. ACS Chem. Biol. 2016, 11, 821. (c) Mukherjee, A. J.; Zade, S. S.; Singh, H. B.; Sunoj, R. B. Chem. Rev. 2010, 110, 4357. (d) Chivers, T.; Laitinen, R. S. Chem. Soc. Rev. 2015, 44, 1725. (e) Lenardão, E. J.; Santi, C.; Sancineto, L. New Frontiers in Organoselenium Compounds; Springer International: New York, 2018. (f) Woollins, J. D.; Laitinen, R. Selenium and Tellurium Chemistry: From Small Molecules to Biomolecules and Materials; Springer: Berlin, 2011. (g) Organoselenium Compounds in Biology and Medicine: Synthesis, Biological and Therapeutic Treatments; Jain, V. K.; Priyadarsini, K. I., Ed.; Royal Society of Chemistry: Cambridge,. (h) Selvakumar, K.; Singh, H. B. Chem. Sci. 2018, 9, 7027. (i) Christensen, M. C.; Florea, I.; Loft, H.; McIntyre, R. S. J. Affective Disord. 2020, 263, 258. (j) Feng, M.; Tang, B.; Liang, S.; Jiang, X. Curr. Top. Med. Chem (Sharjah, United Arab Emirates) 2016, 16, 1200. (k) Sanford, M.; Keating, G. M. CNS Drugs 2012, 26, 435. (l) Sanchez, C.; Asin, K. E.; Artigas, F. Pharmacol. Ther. 2015, 145, 43. (m) Engman, L.; Stern, D.; Frisell, H.; Vessman, K.; Berglund, M.; Ek, B.; Andersson, C.-M. Bioorg. Med. Chem. 1995, 3, 1255. (n) Doering, M.; Ba, L. A.; Lilienthal, N.; Nicco, C.; Scherer, C.; Abbas, M.; Zada, A. A. P.; Coriat, R.; Burkholtz, T.; Wessjohann, L.; Diederich, M.; Batteux, F.; Herling, M.; Jacob, C. J. Med. Chem. 2010, 53, 6954. (o) Pinz, M.; Reis, A. S.; Duarte, V.; da Rocha, M. J.; Goldani, B. S.; Alves, D.; Savegnago, L.; Luchese, C.; Wilhelm, E. A. Eur. J. Pharmacol. 2016, 780, 112. (p) Bernardon, J.-M.; Diaz, P. WO 1999065872 , 1999. (q) Casaril, A. M.; Ignasiak, M. T.; Chuang, C. Y.; Vieira, B.; Padilha, N. B.; Carroll, L.; Lenardão, E. J.; Savegnago, S.; Davies, M. J. Free Radical Biol. Med. 2017, 113, 395. (r) Kumar, S.; Sharma, N.; Maurya, I. K.; Bhasin, A. K. K.; Wangoo, N.; Brandão, P.; Félix, V.; Bhasin, K. K.; Sharma, R. K. Eur. J. Med. Chem. 2016, $123,916$.

(8) (a) Lee, S. M.; Lee, H. R.; Dutta, G.; Lee, J.; Oh, J. H.; Yang, G. Polym. Chem. 2019, 10, 2854. (b) Liu, C.-C.; Mao, S.-W.; Kuo, M.Y. J. Phys. Chem. C 2010, 114, 22316. (c) Yi, Z.; Wang, S.; Liu, L. 
Adv. Mater (Weinheim, Ger.) 2015, 27, 3589. (d) Reddy, M. R.; Kim, H.; Kim, C.; Seo, S. Synth. Met. 2018, 235, 153. (e) Klauk, H. Chem. Soc. Rev. 2010, 39, 2643. (f) Tisovský, P.; Gáplovský, A.; Gmucová, K.; Novota, M.; Pavúk, M.; Weis, M. Org. Electron. 2019, 68, 121. (g) Takimiya, K.; Kunugi, Y.; Konda, Y.; Ebata, H.; Toyoshima, Y.; Otsubo, T. J. Am. Chem. Soc. 2006, 128, 3044. (h) Yamamoto, T.; Takimiya, K.J. Am. Chem. Soc. 2007, 129, 2224. (i) Takimiya, K.; Kunugi, Y.; Konda, Y.; Niihara, N.; Otsubo, T. J. Am. Chem. Soc. 2004, 126, 5084. (j) Ashraf, R. S.; Meager, I.; Nikolka, M.; Kirkus, M.; Planells, M.; Schroeder, B. C.; Holliday, S.; Hurhangee, M.; Nielsen, C. B.; Sirringhaus, H.; McCulloch, I. J. Am. Chem. Soc. 2015, 137, 1314. (k) An, Y.; Oh, J.; Chen, S.; Lee, B.; Lee, S. M.; Han, D.; Yang, C. Polym. Chem. 2018, 9, 593. (l) Chen, G.; Liu, S.; Xu, J.; He, R.; He, Z.; Wu, H.-B.; Yang, W.; Zhang, B.; Cao, Y. ACS Appl. Mater. Interfaces 2017, 9, 4778. (m) Grimsdale, A. C.; Chan, K. L.; Martin, R. E.; Jokisz, P. G.; Holmes, A. B. Chem. Rev. 2009, 109, 897. (n) Zampetti, A.; Minotto, A.; Squeo, B. M.; Gregoriou, V. G.; Allard, S.; Scherf, U.; Chochos, C. L.; Cacialli, F. Sci. Rep. 2017, 7, 1611. (o) Kalyani, N. T.; Dhoble, S. J. Renewable Sustainable Energy Rev. 2012, 16, 2696. (p) Yamaguchi, S.; Xu, C.; Okamoto, T. Pure Appl. Chem. 2006, 78, 721. (q) Arsenyan, P.; Petrenko, A.; Leitonas, K.; Volyniuk, D.; Simokaitiene, J.; Klinavičius, T.; Skuodis, E.; Lee, J.H.; Gražulevičius, J. V. Inorg. Chem. 2019, 58, 10174. (r) Ghosh, T.; Lehmann, M. J. Mater. Chem. C 2017, 5, 12308. (s) Funahashi, M.; Hanna, J.-I. Adv. Mater (Weinheim, Ger.) 2005, 17, 594. (t) Mei, J.; Diao, Y.; Appleton, A. L.; Fang, L.; Bao, Z. J. Am. Chem. Soc. 2013, 135, 6724. (u) Wang, C.; Dong, H.; Hu, W.; Liu, Y.; Zhu, D. Chem. Rev. 2012, 112, 2208. (v) Bujak, P.; KulszewiczBajer, I.; Zagorska, M.; Maurel, V.; Wielgus, I.; Pron, A. Chem. Soc. Rev. 2013, 42, 8895. (w) Okamoto, T.; Yu, C. P.; Mitsui, C.; Yamagishi, M.; Ishii, H.; Takeya, J. J. Am. Chem. Soc. 2020, 142, 9083.

(9) (a) Liu, Z.; Jiang, Y.; Liu, C.; Zhang, L.; Wang, J.; Li, T.; Zhang, H.; Li, M.; Yang, X. J. Org. Chem. 2020, 85, 7386. (b) Ding, C.; Yu, Y.; Yu, Q.; Xie, Z.; Zhou, Y.; Zhou, J.; Song, Z. ChemCatChem 2018 , 10, 5397. (c) Bhunia, S. K.; Das, P.; Jana, R. Org. Biomol. Chem. 2018, 16, 9243. (d) Wen, Z.; Xu, J.; Wang, Z.; Qi, H.; Xu, Q.; Bai, Z.; Zhang, Q.; Bao, K.; Wu, Y.; Zhang, W. Eur. J. Med. Chem. 2015, 90, 184. (e) Kumaraswamy, G.; Ramesh, V.; Gangadhar, M.; Vijaykumar, S. Asian J. Org. Chem. 2018, 7, 1689. (f) Kumar, P.; Kashid, V. S.; Mague, J. T.; Balakrishna, M. S. Tetrahedron Lett. 2014, 55, 5232. (g) Bhat, M. Y.; Kumar, A.; Ahmed, Q. N. Tetrahedron 2020, 76, 131105. (h) Belladona, A. L.; Cervo, R.; Alves, D.; Barcellos, T.; Cargnelutti, R.; Schumacher, R. F. Tetrahedron Lett. 2020, 61, 152035. (i) Song, Z.; Ding, C.; Wang, S.; Dai, Q.; Sheng, Y.; Zheng, Z.; Liang, G. Chem. Commun. 2020, 56, 1847. (j) Xiao, F.; Xie, H.; Liu, S.; Deng, G.-J. Adv. Synth. Catal. 2014, 356, 364. (k) Bettanin, L.; Saba, S.; Doerner, C. V.; Franco, M. S.; Godoi, M.; Rafique, J.; Braga, A. L. Tetrahedron 2018, 74, 3971. (l) Rafique, J.; Saba, S.; Rosário, A. R.; Braga, A. L. Chem. Eur. J. 2016, 22, 11854. (m) Azeredo, J. B.; Godoi, M.; Martins, G. M.; Silveira, C. C.; Braga, A. L. J. Org. Chem. 2014, 79, 4125. (n) Ge, W.; Wei, Y. Green Chem. 2012, 14, 2066. (o) Ferreira, N. L.; Azeredo, J. B.; Fiorentin, B. L.; Braga, A. L. Eur. J. Org. Chem. 2015, 2015, 5070. (p) Yu, Y.; Zhou, Y.; Song, Z.; Liang, G. Org. Biomol. Chem. 2018, 16, 4958. (q) Rodrigues, J.; Saba, S.; Joussef, A. C.; Rafique, J.; Braga, A. L. Asian J. Org. Chem. 2018, 7, 1819.

(10) (a) Bolm, C.; Legros, J.; Le Paih, J.; Zani, L. Chem. Rev. 2004, 104, 6217. (b) Bauer, I.; Knölker, H. J. Chem. Rev. 2015, 115, 3170. (c) Diaz, D. D.; Miranda, P. O.; Padron, J. I.; Martín, V. S. Curr. Org.
Chem. 2006, 10, 457. (d) Fürstner, A. ACS Cent. Sci. 2016, 2, 778. (e) The Chemistry of Organoiron Compounds; Marek, I.; Rappoport, Z., Ed.; Wiley: Chichester, 2014. (f) Iron Catalysis. Fundamentals and Applications; Plietker, B., Ed.; Springer: Heidelberg, 2011.

(11) (a) Fang, X. L.; Tang, R.-Y.; Zhong, P.; Li, J.-H. Synthesis 2009, 4183. (b) Yadav, J. S.; Reddy, B. V. S.; Reddy, Y. J.; Praneeth, K. Synthesis 2009, 1520. (c) Luz, E. Q.; Seckler, D.; Araújo, J. S.; Angst, L.; Lima, D. B.; Rios, E. A. M.; Rampon, D. S. Tetrahedron 2019, 75, 1258.

(12) Rampon, D. S.; Luz, E. Q.; Lima, D. B.; Balaguez, R. A.; Schneider, P. H.; Alves, D. Dalton Trans. 2019, 48, 9851.

(13) da Silva, R. B.; Coelho, F. L.; Rodembusch, F. S.; Schwab, R. S.; Schneider, J. M. F. M.; Rampon, D. S.; Schneider, P. H. New J. Chem. 2019, 43, 11596.

(14) (a) Vrkljan, P. B.; Bauer, J.; Tomisic, V. J. Chem. Educ. 2008, 85, 1123. (b) Wang, X.; Stanbury, D. M. Inorg. Chem. 2006, 45, 3415. (c) Nikolaychuk, P. A.; Kuvaeva, A. O. J. Chem. Educ. 2016, 93, 1267. (d) Bauer, J.; Tomišić, V.; Vrkljan, P. B. J. Chem. Educ. 2012, 89, 540. (e) Laurence, G. S.; Ellis, K. J. J. Chem. Soc., Dalton Trans. $1972,2229$.

(15) Thomé, I.; Nijs, A.; Bolm, C. Chem. Soc. Rev. 2012, 41, 979.

(16) Vieira, A. A.; Azeredo, J. B.; Godoi, M.; Santi, C.; da Silva Júnior, E. N.; Braga, A. L. J. Org. Chem. 2015, 80, 2120.

(17) Hiller, F. W.; Krueger, J. H. Inorg. Chem. 1967, 6, 528.

(18) Monga, A.; Bagchi, S.; Sharma, A. New J. Chem. 2018, 42, 1551.

(19) (a) Van Humbeck, J. F.; Simonovich, S. P.; Knowles, R. R.; MacMillan, D. W. C. J. Am. Chem. Soc. 2010, 132, 10012. (b) Scepaniak, J. J.; Wright, A. M.; Lewis, R. A.; Wu, G.; Hayton, T. W. J. Am. Chem. Soc. 2012, 134, 19350. (c) Smith, J. M.; Mayberry, D. E.; Margarit, C. G.; Sutter, J.; Wang, H.; Meyer, K.; Bontchev, R. P. J. Am. Chem. Soc. 2012, 134, 6516. (d) Ahlers, C.; Dickman, M. H. Inorg. Chem. 1998, 37, 6337.

(20) Jiang, C.; Garg, S.; Waite, T. D. Environ. Sci. Technol. 2015, 49, 14076.

(21) Chalcogenylation of Naphthalene Derivatives Catalyzed by $\mathrm{FeCl}_{3}$ and KI: General Procedure

An oven-dried $10 \mathrm{~mL}$ glass tube was charged with the appropriate naphthalene derivative $\mathbf{1}$ ( $0.5 \mathrm{mmol}, 1.0$ equiv), diorganoyl dichalcogenide 2 or 4 ( $0.25 \mathrm{mmol})$, and $\mathrm{KI}$ (5.0 mol\%, $4.1 \mathrm{mg})$. $\mathrm{FeCl}_{3}(5.0 \mathrm{~mol} \%, 4.0 \mathrm{mg})$ was then weighed quickly, dissolved in DMSO $(2.0 \mathrm{~mL})$, and added to the glass tube. The mixture was stirred at $110{ }^{\circ} \mathrm{C}$ for $24 \mathrm{~h}$ then cooled to r.t. and added to sat. aq $\mathrm{Na}_{2} \mathrm{~S}_{2} \mathrm{O}_{3}(5.0 \mathrm{~mL})$. The resulting mixture was extracted with EtOAc $(3 \times 5.0 \mathrm{~mL})$, and the organic extracts were separated, dried $\left(\mathrm{MgSO}_{4}\right)$, and concentrated under vacuum. The residue was purified by flash chromatography (silica gel, hexaneEtOAc)

1-(Phenylselanyl)-2-naphthol (3a) $)^{6 d}$

Flash chromatography [silica gel, hexane-EtOAc (90:10)] gave a white solid; yield: $145.1 \mathrm{mg}$ (97\%); mp 77-78 ${ }^{\circ} \mathrm{C} .{ }^{1} \mathrm{H}$ NMR (400 MHz, DMSO- $\left.d_{6}\right): \delta=10.21(\mathrm{~s}, 1 \mathrm{H}), 8.26(\mathrm{dd}, J=8.5,1.1 \mathrm{~Hz}, 1 \mathrm{H})$, $7.94(\mathrm{~d}, J=8.9 \mathrm{~Hz}, 1 \mathrm{H}), 7.84(\mathrm{dd}, J=8.1$ and $1.3 \mathrm{~Hz}, 1 \mathrm{H}), 7.46$ (ddd, $J=8.4,6.8,1.4 \mathrm{~Hz}, 1 \mathrm{H}), 7.36(\mathrm{~d}, J=8.9 \mathrm{~Hz}, 1 \mathrm{H}), 7.32$ (ddd, $J=8.0,6.8,1.2 \mathrm{~Hz}, 1 \mathrm{H}), 7.16-7.09$ (m, $5 \mathrm{H}) .{ }^{13} \mathrm{C}$ NMR $(100 \mathrm{MHz}$, DMSO- $\left.d_{6}\right): \delta=158.1,146.1,136.5,133.3,132.5,129.6,129.1$, $128.9,128.0,126.9,126.0,123.6,118.6,108.1 . \mathrm{MS}(\mathrm{EI}): \mathrm{m} / z(\%)=$ 300 (32.2) [ $\left.\mathrm{M}^{+}\right], 298$ (16.1), 220 (100.0), 194 (29.9), 115 (80.8), 102 (13.1), 77 (18.9), 51 (30.8). 